It is pleasing to see that in the home of the labyrinth the plain sense of Cassandra's words becomes clear; it would be even more pleasing if Virgil could be supposed to have known this epigram.

Hertford College, Oxford

STEPHANIE WEST

stephanie.west@hertford.ox.ac.uk

\title{
THE CERBERUS-LIKE FUNCTION OF THE GORGONS IN VIRGIL'S UNDERWORLD (AEN. 6.273-94)
}

In his commentary on Book 6 of the Aeneid, Austin refers several times to Wistrand's observation that Aeneas and his underworld guide, the Sibyl, arrive at an actual 'house of Orcus' modelled by Virgil upon a Greek house of the kind we find described in Vitruvius 6.7.1-2. ${ }^{1}$ Neither Wistrand nor Austin points out that the two infernal travellers leave Orcus' house through the same door by which they first entered. It makes sense that neither would bother to mention this fact, since Greek houses do only have one entrance-way. However, realization that this is the case throws light on the role played by the Hellish monsters listed in 285-9.

Aeneas at first sees a group of personified shapes in the vestibule area on the road side of the entrance-doors (vestibulum ante ipsum primisque in faucibus Orci, 273) and after entering the interior of the house he walks around the edge of the peristyle to the doorway at the far end of the peristyle court facing the entrance (adverso in limine, 279); he then makes his way back through the court - in the centre of which (in medio, 282) the shadowy elm grows - towards the entrance, where the shades of various wild beasts 'are stabled' (Centauri in foribus stabulant, 286). The verb stabulant refers to occupancy of the rooms known as equilia, Vitruvius' word for 'stables', located within the house to the side of the main entrance. Among the horde of beasts in these stables are the Centaurs, the most horse-like of monsters, and also the Gorgons, on which we shall focus attention presently. What has never been pointed out is that these frightening apparitions of Hell clearly offered Aeneas no resistance as he entered the house but inspired terror only as he sought to make his exit through the same entrance-way. This in turn leads us to suppose that they were within their stalls at his moment of entry, but appeared at the stable-doorways (in foribus) in order to block his path as he tries to depart. No wonder Aeneas is terrified (290). He has to get past these Hellish forms in order to leave Orcus' house and get back onto the road that leads to Acheron.

Given their behaviour, a far greater emphasis can now be laid upon the fact that the last shape in the list is that of the three-bodied spectre, forma tricorporis umbrae (289). This unnamed triple-bodied creature denoting Geryon, who is also three-headed, as Hesiod makes explicit at Theog. 287, reminds us of another beast with three heads, namely the Hell-dog Cerberus latratu . . . trifauci (417) on guard in Virgil's underworld at the entrance to Hades on the far side of the infernal water. ${ }^{2}$ Just as Cerberus' task

${ }^{1}$ See R. G. Austin, P. Vergili Maronis Aeneidos Liber Sextus (Oxford, 1977), 118-21 ad 273, 275, 280, 282, 285ff.; and E. Wistrand, 'Virgil's palaces in the Aeneid', Klio 38 (1960), 146-54.

${ }^{2}$ On the mythological parallels between Cerberus and Geryon and on Heracles' dealings with both figures, see my Catabasis: Vergil and the Wisdom-tradition (Amsterdam, 1979), 83-6, where I suggest that both of Heracles' adversaries may have been versions of a 'conflict with monsters' 
is to admit all who enter, but devour those who attempt to leave the underworld, as Hesiod tells us at Theog. 771ff., so it seems that Virgil has assigned to the Hellish apparitions - Centaurs, Scyllas, Briareus, the Hydra, the Chimaera, Gorgons and Harpies, and Geryon - a comparable role in respect of Aeneas' entering and leaving Orcus' house within the underworld.

The original nucleus of all these apparitions is a single Gorgon. Aeneas' fright and the drawing of his sword against the formidable Gorgons and other insubstantial shades until the Sibyl tells him to desist is modelled upon Heracles' fright and the drawing of his sword against the Gorgon Medusa until he was told to refrain by his underworld guide, Hermes. Heracles' encounter with the Gorgon in the underworld is narrated by Apollodorus in his Bibliotheca at 2.5.12, but this mythographer, who consistently ignores Roman literature, ${ }^{3}$ and Virgil are both said by Norden to have drawn their knowledge of this event from a lost epic version of the Catabasis of Heracles, ${ }^{4}$ which Hugh Lloyd-Jones has shown to be an Attic poem, with Eleusinian connections, composed in the mid-sixth century B.C. ${ }^{5}$ How the Gorgons came to be in Orcus' house in the antechamber of Virgil's underworld, instead of on the far shore of the infernal water, where Heracles attacked the Gorgon in the lost epic and where Virgil now locates the monster Cerberus (417), is a separate matter I have dealt with elsewhere. ${ }^{6}$ The purpose of the present note is to point out for the first time the skill with which Virgil has invested these terrifying apparitions in the house of Orcus with a Cerberus-like function.

The University of Ottawa

RAYMOND J. CLARK rjclark@mun.ca

theme, in which the former developed into an underworld figure while the latter simply resembles one. Virgil nevertheless depicts Geryon's shade in Orcus' house.

${ }^{3}$ As recognized by E. Norden, P. Vergilius Maro: Aeneis Buch VI (Leipzig and Berlin, 19263), 5 with n. 2, and C. M. Bowra, 'Orpheus and Eurydice', CQ 2 (1952), at 116.

${ }_{5}^{4}$ Norden (n. 3), loc. cit.

${ }_{5}^{5}$ Hugh Lloyd-Jones, 'Heracles at Eleusis: P.Oxy. 2622 and P.S.I. 1391', Maia 19 (1967), 206-29 = Greek Epic, Lyric, and Tragedy (Oxford, 1990), 167-87. P.Oxy. 2622 = B. Snell and H. Maehler, Pindarus. Pars II. Fragmenta (Leipzig, 1975), fr. 346. Cf. N. Robertson, 'Heracles' 'Catabasis", Hermes 108 (1980), 274-300, and S. Lavecchia, 'P.Oxy. 2622 e il 'Secondo Ditirambo' di Pindaro', ZPE 110 (1996), 1-26.

${ }^{6}$ In 'How Vergil expanded the Underworld in Aeneid 6', PCPS 47 (2001), 103-16. The location of Cerberus just referred to in the text should not be taken to imply that the Hell-dog appears here in the lost Heracles catabasis, since Apollodorus, Bibl. 2.5.12 says that Heracles found him at the gates of Acheron on his way out of the underworld (cf. also Aen. 6.395-6). Cerberus' Virgilian location corresponds rather to where the snakes and monsters of Hell were located in this lost catabasis. This seems not to have been realized by Norden (n. 3), 466.

\section{PROPERTIUS 3.4 AND THE AENEID INCIPIT}

It is common knowledge that Propertius had some acquaintance with the Aeneid prior to its posthumous publication in 18 B.C. Elegy 2.34.63-4, where Virgil is described as engaged in the composition of the Aeneid in the mid-20s B.C., shows Propertius aware of its subject-matter:

qui nunc Aeneae Troiani suscitat arma iactaque Lauinis moenia litoribus. 